\title{
Music in Kamigata Rakugo Performance
}

Catherine Hallett

Australian National University

\begin{abstract}
Rakugo is the Japanese tradition of staged comic storytelling presented by highly trained hanashika storytellers associated with small urban variety theatres called yose, found in the Kamigata and Edo regions. Although yose theatres are associated with spoken rather than musical events, music is an integral component of Kamigata rakugo performance. It is central both to the rendering of a storyteller's performance and to creating the overall atmosphere in the yose theatre. This paper addresses the lack of detailed research on music in Kamigata rakugo performance, particularly in English. It demonstrates and documents the centrality of music in Kamigata rakugo performance, specifically the way that this music, which is rich in symbolism, aids a storyteller's performance and is intrinsically bound up in the hierarchical structure of the storytellers and yose-bayashi ensemble musicians. It focuses on how the music functions in the performances, transmitting meanings and supporting the social structure of the ensemble.
\end{abstract}

\section{Keywords}

Kamigata; rakugo; storyteller; storytelling; yose-bayashi

To link to this article: http://dx.doi.org/10.21159/nv.06.04 


\section{Introduction}

Rakugo ${ }^{1}$ is the Japanese tradition of staged comic storytelling presented by highly trained hanashika storytellers associated with small urban variety theatres called yose, located in the Kamigata and Edo regions. Despite the comparable format and appearance of Kamigata and Edo rakugo, Kamigata storytellers consider music to be an integral component of rakugo performance. ${ }^{2}$ It is central to the rendering of a storyteller's performance, as demonstrated by the inclusion of debayashi (theme songs), ukebayashi (withdrawal songs), hamemono (music and musical sound effects), and aibayashi (joining tunes). ${ }^{3}$ The music also adds to the overall atmosphere created both inside and outside the yose theatre through the sounding of the narimono repertoire. ${ }^{4}$

The yose theatre's hayashi ensemble, which consists of a hosozao shamisen (thin-necked, three-stringed plucked lute) and narimono (percussion and flutes), performs all the music heard in the yose theatre. The term narimono refers to the percussion and flutes of the hayashi ensemble and also to the repertoire of music played solely by these instruments. In order to accurately convey its meaning throughout this paper, the term narimono will be used to delineate both narimono instruments and narimono repertoire. The structure of the yose theatre's hayashi ensemble and the indispensable role it plays in the theatre clearly reflect the etymology of the word hayashi (to be discussed later), and its purpose: to praise and support the storyteller.

The aims of this paper are, firstly, to address the lack of detailed research on music in Kamigata rakugo, particularly in English; and secondly, to demonstrate and document the centrality of music in Kamigata rakugo-specifically the way music, which is rich in symbolism, aids a storyteller's performance and is intrinsically bound up in the hierarchical structure of the storytellers and the hayashi musicians.

This paper has five parts. The first outlines the research methodology, and the second reviews the extant literature on music in rakugo performance. The third provides a brief introduction to rakugo, and the fourth discusses the instrumentation, function, social structures and transmission of music in rakugo. Finally, the central musical components heard regularly during any given rakugo performance are examined within the context of their important contribution to Kamigata yose performance as a whole.

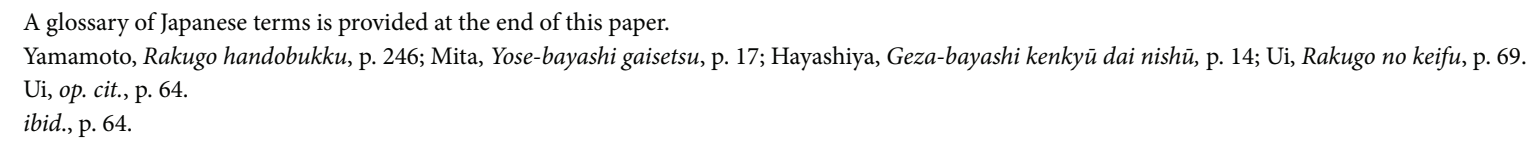

A glossary of Japanese terms is provided at the end of this paper.

Yamamoto, Rakugo handobukku, p. 246; Mita, Yose-bayashi gaisetsu, p. 17; Hayashiya, Geza-bayashi kenkyū dai nishū, p. 14; Ui, Rakugo no keifu, p. 69. Ui, op. cit., p. 64.

ibid., p. 64. 


\section{Research Methodology}

Data for this paper was collected during fieldwork conducted in Osaka between January and February 2008. Interviews were conducted in Japanese with five storytellers and two hayashi shamisen musicians who are affiliated with the Kamigata Rakugo Kyōkai (Kansai Rakugo Association). Set interview questions were used for both storytellers and musicians, but in order to deepen understanding these were followed by unstructured questions relevant to the respondent's circumstances. ${ }^{5}$ Non-participatory direct observation, including video and audio recording, was undertaken in order to obtain an ontological perspective on the yose theatre's hayashi ensemble. The Kamigata Rakugo Kyōkai and master storyteller Hayashiya Somemaru IV ${ }^{6}$ (b. 1949) granted me permission to observe the workings of the hayashi ensemble during rakugo performances from behind the stage at Tenma Tenjin Hanjōtei, the main yose theatre in Osaka. Supplementary collection of data from primary and secondary Japaneselanguage materials (books, journal articles, textbooks, newspaper articles, theatre programs, video and audio recordings) was also undertaken.

\section{Literature on Music in Rakugo Performance}

This literature review briefly describes the existing literature on Kamigata rakugo performance to show the need for more empirical research on music in rakugo, particularly in English.

The extant literature on Kamigata rakugo primarily describes the linguistic and performative aspects of rakugo performance; it pays limited attention to the function, social structures and transmission of the music proceeding, during, and succeeding a storyteller's performance. Japanese-language literature on contemporary Kamigata rakugo performance is abundant. Significant contributors to the literature include Hayashiya Somemaru IV, Katsura Beichō III, Katsura Bunshi V, San’yūtei Enshō, Maeda Isamu, Masaoka Iruru, Mita Jun'ichi, Satake Akihiro, Sekiyama Kazuo and Ui Mushū - the first four of whom are also rakugo storytellers. Literature on contemporary rakugo performance in English is scarce, and focuses on Edo rakugo performance. No explanations are available on why non-Japanese scholars focus on Edo rakugo; however, this focus does explain the scarcity of English-language literature on music in rakugo performance. As mentioned, compared with Edo rakugo, Kamigata rakugo incorporates and places greater emphasis on the inclusion of music to create atmosphere in the yose

5 All interviews were transcribed and translated by the author. While data was drawn from the interviews for use in this paper, in order to maintain anonymity, none of the storytellers or musicians quoted have been identified.

6 A list of the Kamigata rakugo ichimon (artistic families) and the storytellers mentioned here is located at the end of this paper. For more details on the artistic families or specific Kamigata storytellers, see Yamada, Kamigata rakugoka meikan. 
theatre. ${ }^{7}$ The main contributors to the literature on contemporary rakugo performance in English include Lorna Brau, Ian McArthur, Heinz Morioka, Miyoko Sasaki, Matthew Shores, and Kimie Ōshima. Matthew Shores is the only one of these scholars who focuses his research on Kamigata rakugo performance.

Existing literature on music in contemporary rakugo performance is scant, and primarily limited to Japanese-language sources. The English-language writers Lorna Brau, Heinz Morioka and Miyoko Sasaki refer briefly to the presence of debayashi and narimono repertoire in the yose theatre, but they do not examine the function, social structures and transmission of music in rakugo performance. The Japanese-language literature on music in contemporary Kamigata rakugo performance can be divided into three categories: studies, anthologies and dictionaries, and kikkakechō (cue books). The first category includes descriptions of performance elements such as debayashi, hamemono and the narimono repertoire, and it documents the types of music traditionally incorporated into a storyteller's performance. This type of literature fails, however, to acknowledge the way that storytellers engage in innovation in contemporary performance by incorporating aspects such as foreign music, animation music and children's music into their performance. Noteworthy scholars include the aforementioned Hayashiya Somemaru IV, Katsura Beichō III, Katsura Bunga IV, Masaoka Iruru, Mita Jun'ichi, Satake Akihiro and Ui Mushū.

The second category of literature, anthologies or dictionaries, provide synopses or transcriptions of rakugo stories regardless of whether they contain hamemono. It is currently unknown precisely how many rakugo stories contain hamemono because it is unclear how many rakugo stories exist. ${ }^{8}$ Most anthologies are arranged by theme or by storyteller. The main contributors of this literature include Mita Jun'ichi, Nagata Yoshinao, Satake Akihiro, Teruoka Yasutaka, Ui Mushū, the Tōdai Rakugokai and the Koten Geino Kenkyūkai. The third category of literature consists of kikkakechō (cue books) which notate when and where music should be inserted into a rakugo story. Literature in this category is scarce, and limited to sources published by Ōsada Sadao and Tachibana Uchiro. All yose theatre hayashi musicians and storytellers keep cue books with detailed information about rakugo performances containing hamemono; however, these are unpublished.

Yamamoto, op. cit., p. 246; Mita, op. cit., p. 17; Hayashiya, op. cit., p. 14; Ui, op. cit., p. 69.

8 Morioka and Sasaki, Rakugo: The Popular Narrative Art of Japan, p. 9. 


\section{What is Rakugo?}

Rakugo is the oral tradition of staged comic storytelling of the Kamigata (or Kansai) and Edo (or Kantō) regions of Japan, which has been performed regularly since the Edo period (1600-1868). ${ }^{9}$ In this tradition, stories are transmitted through oral interaction (kōtō denshō) from shishō (master) to deshi (pupil, apprentice storyteller). ${ }^{10}$ The stories are called hanashi or rakugo, and are performed by professional storytellers called hanashika or rakugoka, the former terms being preferred in the Kamigata region.

When performing, the storyteller enters the stage, sits with his legs folded under himself (or herself) in the seiza position on a large zabuton cushion placed at centre stage, and tells a story. There are two types of rakugo upon which a storyteller may base a performance. The first, called shinsaku rakugo (literally 'new rakugo'), refers to stories composed during or after the Meiji era (1868-1912). The second, called koten rakugo (literally 'classical rakugo'), refers to stories that predate the Meiji era. ${ }^{11}$ Each of these types of rakugo contains numerous categories of stories, such as otoshi banashi (stories ending with a joke or pun), ninjō banashi (stories of human compassion), kaidan banashi (ghost stories), shibai banashi ('theatre' stories) and ongyoku banashi (stories with instrumental accompaniment from the shamisen (three-stringed plucked lute) or narimono (percussion and flutes)). There is no consensus as to the number or type of representative themes, ${ }^{12}$ and most commonly, anthologies of rakugo are arranged according to storyteller or by theme. ${ }^{13}$

Regardless of the type of rakugo performed, each storyteller's performance lasts for approximately twenty minutes. Each story characteristically consists of a makura (prologue), hondai (main story) and ochi (ending punch line). Storytellers customarily wear a kimono (traditional Japanese garment), or a pair of hakama (long pleated culottelike trousers) and a haori (formal jacket). Storytellers use two props or accessories: a sensu (folding paper fan) and a tenugui (handkerchief/small cotton hand towel). These are said to have been the two items most carried by people during the Edo period..$^{14}$ The sensu can be used to symbolise objects such as chopsticks, scissors, cigarettes or a pipe, while the tenugui can be used to represent items such as a book, a handkerchief or banknotes. ${ }^{15}$

\footnotetext{
Morioka and Sasaki, op. cit., p. 9; Shores, 'Travel and Tabibanashi in the Early Modern Period: Forming Japanese Geographic Identity', p. 107. Osaka Shiritsu Kamigata Engei Shiryōkan (ed.), Kamigata engei taizen, p. 112.

Morioka and Sasaki, op. cit., p. 9.

ibid., p. 9.

3 Aiba, Gendai kamigata rakugo benri jiten; Koten Geino Kenkyūkai (ed.), Gendai rakugo jiten; Nagata, Koten rakugo kanshō jiten; Tōdai Rakugokai (ed.), Rakugo jiten; Ui, op. cit.

14 Brau, Rakugo: Performing Comedy and Cultural Heritage in Contemporary Tokyo, p. 49.

15 Ui, Kamigata hanashi kō, pp. 290-293.
} 
The three main rakugo theatres in the Kamigata region are Tenman Tenjin Hanjōtei, Dōrakutei and Tanabe Yose. The main rakugo theatres in the Edo region include Suehirotei, Suzumoto Engeijō, Asakusa Engei Hōru and Ikebukuro Engeijō. In both regions, there are numerous other chihō yose or chiiki yose (provincial and regional theatres respectively) where one can hear rakugo.

\section{The Yose Theatre's Hayashi Ensemble}

Each element of the ensemble is worth considering, including its instruments, etiology, function and social structure. As mentioned, the yose theatre's hayashi ensemble is composed of a hosozao shamisen ${ }^{16}$ (thin-necked, three-stringed plucked lute) ${ }^{17}$ and narimono instruments (percussion and flutes). Those who play shamisen are referred to as ohayashi-san, after the name of the ensemble (hereafter ohayashi musicians), or gezasan, after the name of the room in which they perform. The former term is preferred in Kamigata rakugo. ${ }^{18}$ The narimono instruments are played by apprentice storytellers. The instruments include but are not limited to percussion instruments such as ōdaiko (large barrel drum), shimedaiko (small barrel drum), okedō (folk drum with two heads lashed together), dora (gong with a knobbed centre), atarigane (small brass hand gong played with a small bone hammer on the inside of the gong), rei (Buddhist sutra bell used to indicate religious services or the entrance of a priest), ekirei (station bells), hyōshigi (wooden clappers), tsuke (striking clappers on a wooden board), kotsuzumi (hourglassshaped drum), ōkawa (small drum), sōban (gong), chanpon (small cymbals) and flutes such as the shinobue (also referred to as takebue; transverse bamboo flute) and nōkan (Noh flute). ${ }^{19}$

Inside the yose theatre, the theatre's hayashi ensemble is seated in a small room called the geza, which is similar to the Kabuki theatre's kuromisu (literally 'black curtain'), the off-stage musicians' room. ${ }^{20}$ From inside the room, the musicians are able to keep an eye on the storyteller through a small window covered by wooden slats and gauze-like fabric. The audience cannot see the hayashi ensemble from their seats in the theatre.

16 Kikkawa, Hōgaku hyakka jiten, p. 497.

17 The hosozao (thin neck) shamisen is the main type of shamisen used in the yose-bayashi, although there are times when the chüzao (middle-thickness neck) shamisen or the futozao (thick neck) shamisen are also used for certain genres of music.

18 Hayashiya, Kamigata rakugo yose-bayashi no sekai kaisetsuhen, p. 63.

19 ibid., p. 1; Katsura, Kamigata yose-bayashi daizenshū kaisetsu, p. 6; Ui, Kamigata hanashi kō, pp. 294-295; Ui, Rakugo no keifu, p. 63; Osaka Shiritsu Kamigata Engei Shiryōkan (ed.), op. cit., pp. 184-185.

20 Hayashiya, Kamigata rakugo yose-bayashi no sekai kaisetsuhen, p. 33; Malm, Traditional Japanese Music and Musical Instruments, p. 241. 


\section{Etiology of the Yose Theatre's Hayashi Ensemble}

In discussing the ensemble, it is important to consider the etymology of the term hayashi and how it is exemplified in the yose theatre. Hayashi is a general term for different types of musical ensembles or musical accompaniments in Japan. ${ }^{21}$ When referring to the hayashi found in the yose- that is, the yose hayashi-the phonetically correct term used to describe the ensemble is 'yose-bayashi', and this term will be used here. The word hayashi can be traced to the nominal form of the transitive verb hayasu (囃す, 速す), meaning 'to favour' or 'to praise. ${ }^{22}$ At the core of the word hayashi is the suggestion 'that the festive mood associated with an instrumental ensemble [yose-bayashi] was created in praise of something. ${ }^{23}$ In Kamigata rakugo performance, this is clearly exemplified through the ensemble's sounding of the debayashi before a storyteller takes the stage and the ukebayashi after a storyteller's performance, and also through the sounding of hamemono incorporated during their performance.

\section{The Function of the Ensemble}

The music played by the ensemble is created 'to praise' or 'to favour' and support the storyteller. In the past it was common for a storyteller's wife to accompany her husband's rakugo performance with the shamisen, thus outwardly displaying support and encouragement for her partner. A particularly noteworthy example of this was Hayashiya Tomi (1883-1970), an ohayashi musician who was married to and accompanied her husband Hayashiya Somemaru II (1867-1952). Today, of those affiliated with the Kamigata Rakugo Kyōkai, there are two ohayashi musicians who are married to storytellers. Ohayashi musician Hayashiya Kazume (b. 1961) is married to Hayashiya Kosome V (b. 1963), and ohayashi musician Nakata Manami (b.?) is married to Katsura Harusame (b. 1964). ${ }^{24}$ Interestingly, in 2008, one of the Kamigata rakugo storytellers interviewed as part of this research explicitly likened the relationship between the ohayashi musicians and storyteller to that between a husband and wife:

The relationship between shamisen player and storyteller is similar to that between a husband and wife. The storyteller must respect and revere the shamisen player and conversely the shamisen player must support the storyteller. ${ }^{25}$

\footnotetext{
21 Kikkawa, op. cit., p. 827.

22 Hayashiya, Kamigata rakugo yose-bayashi no sekai kaisetsuhen, p. 33; Imada, 'Lupin III and the Gekiban Approach', p. 179.

23 Imada, op. cit., p. 179

24 Yamada, op. cit., pp. 114-115.

25 「落語とお囃子の人は夫婦のようなものですね。落語家はお囃子さんのことを尊敬しなければいけない。お囃子さんも落語家のことを立てなければ いけない。そういう縁の下の力もちですけれども、とても大事な役目になってます。」
} 


\section{Social Structures and Transmission of Music in Rakugo Performance}

In rakugo, stories and music are transmitted through oral interaction (kōtō denshō) from master to apprentice storyteller. ${ }^{26}$ Tokita and Hughes state that the traditional arts' 'reliance on oral transmission required the stability of social structure, as well as mechanisms and materials that became established and institutionalised in a variety of ways. ${ }^{27}$ All Kamigata storytellers and the majority of ohayashi musicians belong to an ichimon (artistic family) in which all performers follow and abide by a strict autocratic hierarchical structure. Master storytellers have substantial influence in the yose theatre, while ohayashi musicians have authority in the musical arena of the yose theatre. Apprentice storytellers are musically subservient to the ohayashi musicians; however, in the long run they will eventually become professional storytellers and at some stage have authority over the ohayashi musicians.

The configuration of the yose-bayashi ensemble contains a dichotomy based on gender and one's status as professional or amateur. The ohayashi musicians are professionally trained musicians who play the shamisen. The narimono instruments are played by apprentice storytellers, who are considered-and consider themselves to be-amateur musicians. The vast majority are men, and it is part of their formal rakugo training. This genderbased functional dichotomy is said to be evidence that rakugo parodies and inverts the conventions of Kabuki, in which all music is played by professional male musicians. ${ }^{28}$

All musicians, whether considered professional or amateur, practice their instrument and learn the prescribed musical components alone. There are only three occasions when the yose-bayashi ensemble practices together: first, when they are required to play hamemono that deviate from the prescribed accompaniment inserted in a particular rakugo story; second, when they incorporate hamemono into a rakugo story that does not usually contain hamemono; and finally, when a storyteller has selected, composed or received a new debayashi.

In the case where a storyteller adopts a new debayashi or incorporates hamemono into their performance, one of the ohayashi musicians will transcribe the melody and place the score in the geza (off-stage musicians' room) so that all the musicians are aware of the tune. If they discover immediately before a performance that an ohayashi musician is unfamiliar with a new debayashi, aibayashi or hamemono, they will ask a colleague to send them the score via mobile phone text (sha-merru). The notation of the scores

\footnotetext{
26 Morioka and Sasaki, op. cit., p. 1; Osaka Shiritsu Kamigata Engei Shiryōkan (ed.), op. cit., p. 112; Ōshima, Rakugo and Humour in Japanese Interpersonal Communication, p. 99.

27 Tokita and Hughes, 'Context and Change in Japanese Music', p. 14.

28 Hayashiya, Kamigata rakugo yose-bayashi no sekai kaisetsuhen, p. 34.
} 
usually exemplifies the skeletal structure of the melody with minimal expressive techniques noted. It is interesting to note that while musicians have certain agreedupon ways to play a piece of musical accompaniment, there is no correct rendition of a piece; thus there may be several slightly different ways in which a piece of music could be heard.

As part of their apprenticeship, apprentice storytellers are required to learn a narimono instrument-either percussion or flute. One of the storytellers interviewed as part of this research indicated that learning an instrument is fundamental to rakugo training, as it aids in developing a sense of rhythm that is integral in storytelling.

[Participating in the yose-bayashi ensemble] greatly improves your rhythm in storytelling. Some people have a sense of rhythm, while others have no sense of rhythm. Rhythm is very important in rakugo. People who are not musical are also bad at rakugo. They have a bad ear. But if you continue to practice the drums or shamisen, even if you have a bad sense of rhythm, your playing will improve and so will your storytelling. ${ }^{29}$

The ohayashi musicians I interviewed also revealed that apprentice storytellers are not scheduled on a roster to play with the yose-bayashi ensemble. Instead, those who have been asked to assist their master will assume the role of musician when required. Once an apprentice storyteller has become a fully-fledged storyteller, (s)he is rarely required to play in the yose-bayashi ensemble. The only time a storyteller may assume a role in the yose-bayashi ensemble is when (s)he is performing in a very small provincial or regional yose where only two or three storytellers are performing, and no or very few apprentice storytellers are available. In these cases, master storytellers will work on a rotational basis and assist each other.

\section{Musical Components in Kamigata Rakugo}

The central musical components heard during a rakugo performance include debayashi, ukebayashi, aibayashi, hamemono, and narimono repertoire (ichiban daiko, niban daiko, nakairi shagiri and hane daiko). ${ }^{30}$ Consideration of the presence, role and function of each of these events will demonstrate the centrality of music in generating the excitement and anticipation for both storyteller and audience that is critical to the jovial atmosphere characteristic of the Kamigata yose theatre.

\footnotetext{
29 「お噺子、お㗍子のリズムに大いに勉強なるし、人間って、リズム感のある人と全くダメな人、いてるでしょ。で、落語って、リズムが大事やと僕思うの㸚。 歌の下手な人は、落語もダメ... 耳が悪い...と思う。だから太鼓とか三味線やってれば、ま、ある程度ダメな人でも、やれば、リズムがよくなる、そうなる と、しやべりが上手くなる、と僕は思うので。あまりみんなに言わないでほしいんやけど、音痴な人は落語ダメです。平均だめです。見てて、いや、自分の ことは棚に上げてね、けど、そう思うわ。だから太鼓とかやってると、笛でも、やつは絶対に噺子にいきてくると思います。」

30 Ui, Rakugo no keifu, p. 64.
} 


\section{Debayashi}

The debayashi (or agari) is the tune heard before each storyteller takes the stage. ${ }^{31}$ It indicates to a knowledgeable audience which performer will be appearing next in the program. ${ }^{32}$ Storytellers often refer to debayashi as their theme song (tèma songu), ${ }^{33}$ while English academic discourse describes them as entrance music ${ }^{34}$ or entrance signature tunes. $^{35}$ Today, every professional Kamigata storyteller is associated with a specific personalised debayashi.

Although debayashi are not the central component of a storyteller's performance, these tunes have substantial significance for performers. Academics discussing rakugo claim that the function of the debayashi is to signify to the audience which storyteller is about to take the stage. ${ }^{36}$ While this statement is correct, it only holds true for those who frequently visit the yose theatre and or are avid rakugo fans. Of the storytellers interviewed as part of this research, three provided particularly insightful comments regarding the personal significance of the debayashi to their performance. The first indicated that the function of their debayashi is to assist them in focusing on their performance before they come on stage, while simultaneously 'boosting and confirming [their] inner spirit. ${ }^{37}$

The same storyteller also likened the function of the debayashi to the function of theme songs for television programs, suggesting that when a person hears the theme song for their favourite program coming from the television they feel excited that the show will begin soon. In a similar way, when audience members hear the debayashi of their favourite storyteller, they too feel excited that this person will soon take the stage. ${ }^{38} \mathrm{~A}$ second storyteller said that he places great importance on his debayashi because when it is playing and the excitement is building, he feels like the audience is saying to him, 'please, we are looking forward to your performance', ${ }^{39}$ which inspires him to do his best. A third storyteller suggested that the function of his debayashi was to motivate him to do his best before he took the stage:

The longer I use [my debayashi]...the deeper I consider aspects such as the way in which I take the stage prior to my performance, yes, the more

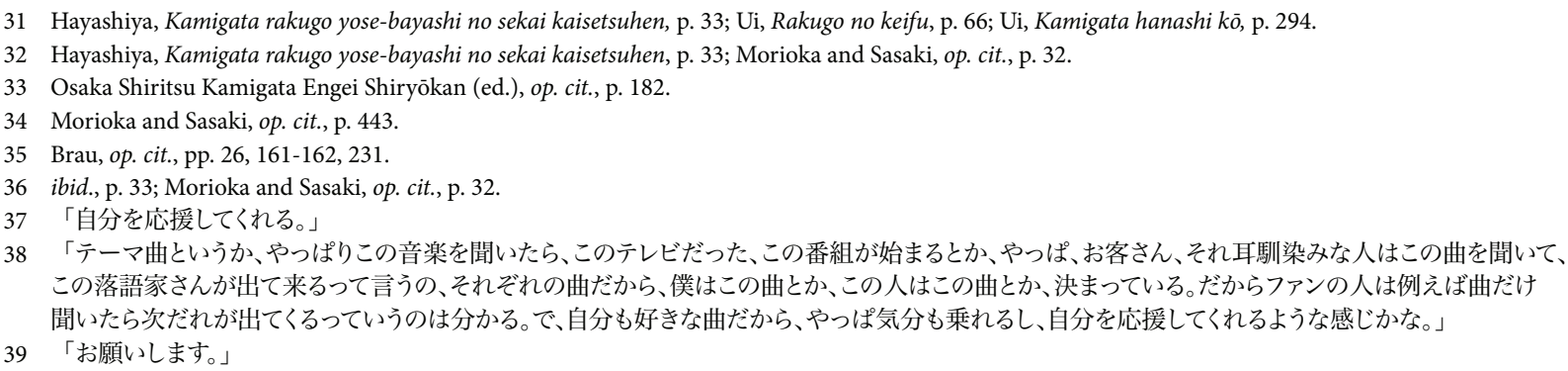


familiar I am with my debayashi, the more of a motivation is it is for me to succeed. ${ }^{40}$

The literature on rakugo indicates that many debayashi derive from pre-existing fragments of traditional Japanese music genres such as nagauta (long song), jiuta (songs of the country), gidayu (recitation), Edo hauta (Edo short song), Kamigata hauta (Kamigata short song), kouta (short song) and jōruri (recitation). ${ }^{41}$ Examples of debayashi that derive from such genres include Hayashiya Somemaru IV's debayashi 'Shōfudatsuki' (nagauta), Katsura Jakujaku’s (b. 1960) debayashi 'Kajiya' (nagauta), Katsura Yoneza's (b. 1965) debayashi 'Kanjinchō - Sono Ichi' (nagauta), Katsura Sanjaku’s (b. 1970) debayashi 'Tatsumi no Hidari Duma' (kouta), Katsura Sankin's (b. 1971) debayashi 'Kisenkuzushi' (jiuta), and Shōfukutei Gakko’s (b. 1954) debayashi 'Fukagawakuzushi' (hauta).

An examination of the list of the approximately 120 debayash ${ }^{42}$ currently in use by Kamigata storytellers revealed that while the vast majority of theme songs do derive from fragments of traditional Japanese music genres, a number of tunes derive from foreign songs, popular songs, children's songs and animation songs. ${ }^{43}$ Noteworthy examples include Shōfukutei Jinchi's (b. 1952) debayashi 'Okurahoma Mikusā', which derives from the American folk dance music 'Oklahoma Mixer'; Katsura Fukusha's (b. 1961) debayashi 'Kusakeiba', deriving from the American minstrel song 'Camptown Races'; Katsura Fukuraku's (b. 1959) debayashi 'Zundoko Sansagari', which is an arrangement of the Japanese popular song 'Zundoko Bushi'; Shōfukutei Kakushō's (b. 1960) debayashi, which derives from the animation song 'Harisu no Kaze'; and Katsura Bunbuku's (b. 1953) debayashi 'Mari no Tonosama', which derives from the children's song 'Mari no Tonosama'.

It is yose theatre tradition that the least-experienced storyteller performs first and the most experienced and eminent storyteller performs last. In accordance with this custom, the storyteller who performs first will take the stage to the debayashi titled 'Ishidan', literally meaning 'a flight of stone steps. ${ }^{44}$ The function of this tune is to symbolically represent a storyteller making their way step-by-step, flight-by-flight to becoming an eminent performer with a successful career. ${ }^{45}$ According to one of the storytellers I interviewed, the sounding of 'Ishidan' before the first storyteller enters the stage also

\footnotetext{
40 「段々使っている内に...それあわせて、高座に出るまでも歩きかたとか、はい、またその出囃子に慣れると自分のモチベーションっていうのもあがると か。」

41 Ui, Kamigata hanashi kō, pp. 294-295; Ui, Rakugo no keifu, pp. 66-68.

42 Shōfukutei, 'Kamigata hanashika debayashi', p. 10; Osaka Furitsu Kamigata Engei Shiryōkan (ed.), op. cit., p. 182.

43 Osaka Furitsu Kamigata Engei Shiryōkan (ed.), op. cit., p. 182.

44 Hayashiya, Kamigata Rakugo yose-bayashi no sekai kaisetsuhen, p. 129; Katsura, Kamigata yose-bayashi daizenshü kaisetsu, p. 16; Osaka Furitsu Kamigata Engei Shiryōkan (ed.), op. cit., p. 182.

45 Hayashiya, Kamigata rakugo yose-bayashi no sekai kaisetsuhen, p. 129.
} 
symbolically indicates that the audience will experience continuous amusement as it hears many renowned performers.

If a storyteller's master dies or otherwise stops performing, they may adopt their master's debayashi and their name, even if they have already been initiated as a fully-fledged storyteller and have selected their own debayashi. Receiving the name of a very successful and popular storyteller is a very big honour for more junior performers as it proves that one has become a big success. This tradition is also present in Kabuki. In both rakugo and Kabuki it is referred to as shumei. At the time of writing, the most recent example of the process of shümei took place on 20 July 2012 when Katsura Sanshi (b. 1943) took on the name Katsura Bunshi from his master Katsura Bunshi V (1930-2005), thus becoming Katsura Bunshi VI. At this stage Katsura Bunshi VI's debayashi remains 'Nokisu', just as it was when he was known by his former stage name of Katsura Sanshi. Katsura Bunshi V's debayashi was 'Kakutanzen'. Another example of the process of shumei is the adoption of the debayashi 'Shōfudatsuki' by Hayashiya Somemaru IV, which had been used by his former master, Sanyūtei Enshō VI (1900-1979). In turn, Hayashiya Somemaru IV's apprentice storyteller Hayashiya Someji III (b. 1961) subsequently adopted Hayashiya Somemaru IV's former debayashi, titled 'Fuji Musume'.

As mentioned, when an apprentice storyteller has completed the zenza period of rigorous training involved in becoming a storyteller, (s)he will be told that it is time to select a debayashi ${ }^{46}$ There is no fixed process through which a debayashi is selected; rather, according to the ohayashi musicians interviewed, it is customary for the leader of the yose-bayashi ensemble (usually the oldest and most experienced shamisen player in the ensemble), the apprentice storyteller's master and the apprentice himself or herself to mutually agree on a tune. The leader of the yose-bayashi ensemble has input into deciding a storyteller's debayashi for two reasons: they are aware of appropriate repertoire, and they have observed the apprentice storyteller's progress throughout their apprenticeship. The type of debayashi selected usually accentuates the personality and character of the storyteller. It can be a preexisting tune or a unique composition. The title of the debayashi selected is documented at the yose theatre and becomes officially taken: no other storytellers in the region can use the tune.

\section{Ukebayashi}

Ukebayashi (withdrawal melody), also referred to as uke for short or sagebayashi, are melodies similar to debayashi and can be applied in two differing contexts as part of a

46 ibid., p. 129. 
storyteller's rakugo performance. First, they may be sounded at the conclusion of the ochi (punch line) of a rakugo story to signify the end of a storyteller's performance. Second, they can also be used to separate multiple kobanashi (short rakugo stories) performed by a single storyteller. ${ }^{47}$ In both cases, ukebayashi are representative of a storyteller telling the audience, 'yes, it is finished, it is finished, there is nothing more'. Today, rather than being a separate piece of music, the ukebayashi is often the proceeding storyteller's debayashi, ${ }^{48}$ meaning that the function of the debayashi is essentially twofold. Debayashi introduce one storyteller to the stage, while also signifying the end of the prior performance.

Ukebayashi are only used as part of a storyteller's rakugo performance in the Kansai region; thus, they are characteristic of Kamigata rakugo. According to Hayashiya Somemaru IV, at the conclusion of the Pacific War when there was a significant shortage of yose-bayashi musicians, Yoshimoto Kōgyo ${ }^{49}$ were forced to make tape recordings of tunes to ensure that ukebayashi could still be heard in yose theatre. ${ }^{50}$ According to Hayashiya Somemaru IV, ukebayashi are not heard at the conclusion of a rakugo performance in Edo rakugo. As soon as a storyteller from the Edo region concludes their ochi (punch line), there is silence. This is used to serve as a lingering memory of the time in Edo rakugo when music was not used as part of a performance. ${ }^{51}$ In an Edo-centric monograph on rakugo, authors Morioka and Sasaki allude to the use of ukebayashi as part of a rakugo performance. However, they do not provide precise details on the use of ukebayashi, so this source does not confirm whether these tunes are only characteristic of Kamigata rakugo or are indeed a recent addition to Edo rakugo performance. ${ }^{52}$

There are multiple prescribed ukebayashi melodies played by the ohayashi musicians and those who play the narimono instruments. Ukebayashi melodies are composed in each of the mainstream tunings of the shamisen: honchōshi (literally 'original tuning'), niagari (literally 'raise the second') and sansagari (literally 'lower the third'). Melodies are selected in accordance with the tuning of the proceeding debayashi. ${ }^{53}$ If the proceeding storyteller's debayashi were in the tune of niagari, then the ukebayashi selected would be one that is also in the tune of niagari.

\footnotetext{
47 Katsura, Kamigata yose-bayashi daizenshū kaisetsu, p. 198; Morioka and Sasaki, op. cit., p. 33; Hayashiya, Geza-bayashi kenkyū dai nishū, p. 3; Hayashiya, Kamigata rakugo yose-bayashi no sekai kaisetsuhen, pp. 101, 125, 180.

48 Hayashiya, Kamigata rakugo yose-bayashi no sekai kaisetsuhen, p. 125, 180; Katsura, Kamigata yose-bayashi daizenshü kaisetsu, p. 2, 198.

49 Yoshimoto Kōgyō was founded in 1912 as a traditional theatre, and is now a major Japanese entertainment conglomerate.

50 Hayashiya, Kamigata rakugo yose-bayashi no sekai kaisetsuhen, pp. 125, 180; Katsura, Kamigata yose-bayashi daizenshū kaisetsu, pp. 2, 198.

51 Hayashiya, Geza-bayashi kenkyū dai nishū, p. 14.

52 Morioka and Sasaki, op. cit., p. 33.

53 Hayashiya, Kamigata rakugo yose-bayashi no sekai kaisetsuhen, p. 180.
} 
Aibayashi

Aibayashi are joining songs. ${ }^{54}$ Today, a typical Kamigata yose theatre session consists of a number of variety acts including rakugo stories performed by storytellers; recitations such as kōdan (formally kōshaku; a professional narrative art form), performed by narrators; misemono ${ }^{55}$ (variety acts) such as tricks, acrobatics, special abilities, mimicry and dance; and manzai (two-person stand-up comedy), ${ }^{56}$ performed by comedians. ${ }^{57}$ At the end of a rakugo performance and preceding a kodan or misemono performance, the ensemble plays an aibayashi if the stage needs to be reset or the performers need to change their costumes. ${ }^{58}$

\section{Hamemono}

Hamemono (music and musical sound effects), also referred to as kōka ongaku, are a unique feature of Kamigata rakugo, and do not characteristically occur in Edo rakugo. ${ }^{59}$ In order to engage fully in a Kamigata rakugo performance containing hamemono, it is worthwhile understanding the purpose and application of this musical element. Hamemono are short melodic or rhythmic phrases that occur during a storyteller's rakugo performance to accompany specific stage actions, set moods, establish locations, identify characters or reflect unspoken thoughts. ${ }^{60}$ Many of the melodic and rhythmic phrases used as hamemono derive from kabuki geza ongaku (Kabuki offstage music). ${ }^{61}$ Like debayashi, hamemono are also taken from traditional music genres such as nagauta, jiuta, gidayū, Edo hauta, Kamigata hauta, zokkyoku and jōruri. ${ }^{62}$ Hamemono are characteristically found in ongyoku banashi (rakugo stories with shamisen or narimono accompaniment), but these days some storytellers include hamemono in stories that do not typically contain music.

Hamemono are played by the yose-bayashi ensemble. The ohayashi and narimono musicians keep kikkakecho (cue books) in which they maintain a record of the rakugo stories that contain hamemono, what melodic or rhythmic phrases are required, and where they are to be inserted. ${ }^{63}$ Most kikkakecho record the name of the rakugo story,

\footnotetext{
54 ibid., p. 125; Katsura, Kamigata yose-bayashi daizenshū kaisetsu, p. 2.

55 For further information on misemono (variety acts), see Kodera, Misemono zasshi; Nobuhiro, 'Yose misemono'; Sekiyama, Yose misemono zasshi; Sekiyama, Yose misemono.

56 Maeda, Kamigata engei jiten, pp. 111-17.

57 Morioka and Sasaki, op. cit., p. 2.

58 Hayashiya, Geza-bayashi kenkyū dai isshu, p. 14; Hayashiya, Kamigata rakugo yose-bayashi no sekai kaisetsuhen, p. 125; Katsura, Kamigata yose-bayashi daizenshū kaisetsu, pp. 194-196.

59 Yamamoto, op. cit., p. 246; Mita, Yose-bayashi gaisetsu, p. 17; Ui, Rakugo no keifu, p. 69.

60 Katsura, Kamigata yose-bayashi daizenshü kaisetsu, p. 1.

61 Osaka Shiritsu Kamigata Engei Shiryōkan (ed.), op. cit., p. 183.

62 This was also mentioned in discussion on the debayashi. Ui, Kamigata hanashi kō, pp. 294-295; Ui, Rakugo no keifu, pp. 66-68.

63 Hayashiya, Kamigata rakugo yose-bayashi no sekai kaisetsuhen, p. 93.
} 
the phrase uttered by the storyteller where the hamemono is to be inserted, and the title of the melody or rhythmic pattern to follow the utterance. There are discrepancies in the application of hamemono between ichimon (artistic families) and even between individual performers of the same family. ${ }^{64}$ Many ohayashi musicians keep multiple entries for a particular rakugo story detailing each storyteller's desired variations to the prescribed melodic and rhythmic phrases. ${ }^{65}$

Some storytellers also choose to add melodic or rhythmic phrases to stories that do not typically contain hamemono so as to personalise the story, demonstrating the dynamic and fluid nature of this performance art. The ohayashi and narimono musicians will also keep records of these variations. If an ohayashi or narimono musician is unaware of a particular storyteller's approach to the application of hamemono in their rakugo story, they will seek advice from another ohayashi musician, their master or the storyteller themselves. In cases where the application of hamemono is difficult, the yose-bayashi ensemble will practice with a storyteller before they perform. It is currently unclear how much liberty storytellers have to deploy and alter hamemono in rakugo performances. Many publications detail the types of melodies and rhythms used as hamemono, ${ }^{66}$ but there is limited documentation on which hamemono are inserted into each story. Examples of rakugo stories containing hamemono are Tenka Ichi Ukare No Kuzu Yori, ${ }^{67}$ Atagoyama, ${ }^{68}$ Tonari No Sakura, ${ }^{69}$ Keikoya $^{70}$ and Karajaya. ${ }^{71}$

\section{Narimono repertoire}

Ichiban daiko, literally meaning 'number one drum', is a rhythm played on an ódaiko (large barrel drum) with nagabachi (long [drum] sticks) ${ }^{72}$ outside of a yose theatre to announce that a rakugo performance will soon begin. The sounding of the ichiban daiko rhythm is a convention adopted from Kabuki for use in the yose theatre. In the context of the yose theatre, this convention occurs thirty minutes before a rakugo session and is typically performed by an apprentice storyteller. ${ }^{73}$ The structure of an ichiban daiko rhythm can be divided into three sections. Initially, the percussionist rubs their nagabachi around the edge of the drum. The sound made by the sticks and edge of the drum rubbing together is perceived to sound 'kara-kara-kara (カラカラカラ)'.

\footnotetext{
64 Osaka Shiritsu Kamigata Engei Shiryōkan (ed.), op. cit., p. 183.

65 Hayashiya, Kikkakechō.

66 Hayashiya, Kamigata rakugo yose-bayashi no sekai kaisetsuhen, pp. 153-179; Katsura, Kamigata yose-bayashi daizenshū kaisetsu, pp. $106-191$.

67 Osada, 'Kamigata rakugo hamemono kikkakechō 3', p. 17.

68 Osada, 'Kamigata rakugo hamemono kikkakechō 1', p. 19.

69 Osada, 'Kamigata rakugo hamemono kikkakechō 8', p. 47.

70 Osada, 'Kamigata rakugo hamemono kikkakechō 3', p. 23.

ibid., p. 17.

Hayashiya, Kamigata rakugo yose-bayashi no sekai kaisetsuhen, p. 180.

73 Katsura, Kamigata yose-bayashi daizenshū kaisetsu, p. 202.
} 
In Japanese, 'kara-kara' is an onomatopoeic word that represents the sound of a wooden sliding door opening or closing. To those around the yose theatre, this sound signifies that the doors of the theatre will soon open. The central component of ichiban daiko is a rhythm played on the skin of the drum and is perceived to sound 'don-don-don-to-koi (どんどん、どんと来い)'. In Japanese, the word 'koi' is the imperative form of the verb ' $k u r u$ ', which means 'to come. ${ }^{74}$ This rhythm symbolically calls people to the theatre. At the conclusion of the rhythm, the percussionist places their sticks in the shape of the character for 'hairu' (入), which means 'to enter', thus signalling to the audience that they should enter the theatre. ${ }^{75}$

Niban daiko, literally meaning 'number two drum', is a second rhythm played by the narimono instruments shimedaiko (small barrel drum), ōdaiko (large barrel drum) and nōkan (Noh flute) five minutes before the curtain opens. The niban daiko rhythm is another convention adopted from Kabuki for use in the yose theatre. ${ }^{76}$ The rhythm of niban daiko is perceived to sound 'o-ta-fuku-koi-koi-kane-motte-koi-koi (お多福来い) 来い、金持つて来い来い)'. In Japanese, 'ta' means 'many'; 'fuku' means 'good fortune'; 'kane' means 'money'; 'motte' is the imperative form of the verb 'motsu', which means 'to bring'; and 'koi', as mentioned before, means 'to come'. This rhythm symbolically expresses gratitude to the patrons for waiting so patiently and indicates that the performance will begin shortly. It also appeals to the audience to return to the theatre to support them in their career. The theatre will remain open and flourish if there is a large audience because it is the audience who pays to watch them perform. ${ }^{77}$

Nakairi shagiri is a rhythm played to indicate the beginning of the intermission. It is played by the narimono instruments and is preceded by the vocalisation 'onakairi' by a musician from the yose-bayashi ensemble. ${ }^{78}$

At the conclusion of a rakugo performance, a rhythm referred to as hane daiko, bare daiko or oidashi is played by the $\bar{o}$ daiko. ${ }^{79}$ In the past the shimedaiko was also used. ${ }^{80}$ This rhythm is perceived to sound 'deteke-deteke...ten-ten-bara-bara (出てけ出てけ...てん てんバラバラ)'. ${ }^{81}$ In Japanese, 'dete' is the imperative form of the verb 'deru', meaning

\footnotetext{
74 Osaka Shiritsu Kamigata Engei Shiryōkan (ed.), op. cit., p. 183; Morioka and Sasaki, op. cit., p. 32; Katsura, Kamigata yose-bayashi daizenshū kaisetsu, p. 202.

75 Katsura, Kamigata yose-bayashi daizenshū kaisetsu, p. 202.

76 Hayashiya, Kamigata rakugo yose-bayashi no sekai kaisetsuhen, p. 181.

77 Osaka Shiritsu Kamigata Engei Shiryōkan (ed.), op. cit., p. 183; Katsura, Kamigata yose-bayashi daizenshū kaisetsu, p. 203 ; Brau, op. cit., p. 161.

78 Hayashiya, Kamigata rakugo yose-bayashi no sekai kaisetsuhen, p. 181.

79 Katsura, Kamigata yose-bayashi daizenshū kaisetsu, p. 207; Hayashiya, Kamigata rakugo yose-bayashi no sekai kaisetsuhen, p. 182; Osaka Shiritsu Kamigata Engei Shiryōkan (ed.), op. cit., p. 183.

80 Hayashiya, Kamigata rakugo yose-bayashi no sekai kaisetsuhen, p. 182.

81 Osaka Shiritsu Kamigata Engei Shiryōkan (ed.), op. cit., p. 183.
} 
'to leave', and ' $k e$ ' is the short form of the imperative verb ' $i k e$ ', which means 'to go' or 'to proceed'. The performer is symbolically telling patrons to leave the theatre. ${ }^{82}$

\section{Conclusion}

This paper has demonstrated and documented the centrality of music in Kamigata rakugo-specifically the way that the music, which is rich in symbolism, aids a storyteller's performance and is intrinsically bound up in the hierarchical structure of storytellers and yose-bayashi ensemble musicians. First, the etymology of the word hayashi was shown to clearly reflect the purpose of the yose-bayashi ensemble, which is to praise and support the storyteller. This purpose was exemplified through the instrumentation of the yose-bayashi ensemble, with its dichotomy of professional (ohayashi) and amateur (narimono) musicians and the ensuing strict autocratic hierarchical structure among yose-bayashi musicians and storytellers. Second, an examination of the central musical components heard during a given rakugo performance further exemplified the role of music in the Kamigata yose theatre. Current storytellers likened their debayashi to a motivational song or theme song, considering it something that 'boosts and confirms their inner spirit'. The sounding of ukebayashi succeeding a storyteller's performance and the aibayashi preceding a variety act were also seen as a means of ensuring that the jovial atmosphere created by one performer lingers on into the next performance. Hamemono, which occur primarily during ongyoku banashi rakugo performances, add a multidimensional element to a performance, helping to construct the imaginary world created by a storyteller. The use of narimono repertoire (ichiban daiko, niban daiko, nakairi shagiri and hane daiko) both inside and outside the yose theatre also provides the ceremonial opening and closing to a performance.

Music is a central component of Kamigata rakugo performance, creating and maintaining excitement and anticipation throughout the yose theatre. Further research on the current application and types of music that a storyteller selects to incorporate into rakugo performances will provide additional insights into the music-making process and substantiate evidence for the importance of music in the Kamigata yose theatre. It is also inferred that such research will provide valuable information on other aspects of social interaction among rakugo storytellers and yose-bayashi musicians.

82 Katsura, Kamigata yose-bayashi daizenshū kaisetsu, pp. 206-207; Osaka Shiritsu Kamigata Engei Shiryōkan (ed.), op. cit., p. 183 
New Voices Volume 6

\section{Glossary of Japanese Terms}

Aibayashi [合囃子]: joining tune

Agari [上がり]: entrance music; a storyteller's theme song (also debayashi)

Atarigane [あたり鉦]: small brass hand gong played with a small bone hammer on the inside of the gong

Bare daiko [バレ太鼓]: a rhythm played at the conclusion of a rakugo performance (also hane daiko, oidashi)

Chanpon [チャンポン]: small cymbals (also chappa)

Chappa [チャツパ]: small cymbals (also chanpon)

Chihō yose [地方寄席]: provincial yose theatre

Chiiki yose [地域寄席]: regional yose theatre

Chüzao shamisen [中棹三味線]: shamisen with a neck of middle thickness

Debayashi [出囃子]: entrance music; a storyteller's theme song (also agari)

$\operatorname{Deshi}$ [弟子]: pupil; apprentice storyteller

Dora [銅鑼]: gong with a knobbed centre

Edo [江戸]: the Kantō region of Japan

Ekirei [駅鈴]: station bells

Futozao shamisen [太棹三味線]: thick-necked shamisen

Geza [下座]: off-stage musicians' room

Geza-san [下座さん]: specifically refers to the women (shamisen players) of the yose-bayashi ensemble (also ohayashisan)

Giday $\bar{u}$ [義太夫]: recitation (traditional Japanese music genre)

Hakama [袴]: long, pleated culotte-like trousers

Hamemono [ハメモノ・嵌め物]: music and musical sound effects incorporated into Kamigata rakugo perfomances (also kōka ongaku)

Hanashi [噺]: stories used in rakugo

Hanashika [噺家]: rakugo storyteller, synonymous with rakugoka (hanashika is preferred in the Kamigata region)

Hane daiko [八ネ太鼓]: a rhythm played at the conclusion of a rakugo performance (also bare daiko, oidashi)

Haori [羽織]: formal jacket

Hauta [端唄]: short song

Hayashi [囃子]: general term for different types of musical ensembles or musical accompaniments in Japan 
Honchōshi [本調子]: literally 'original tuning'; a tuning of the shamisen

Hondai [本題]: main story

Hosozao shamisen [細棹三味線]: thin-necked shamisen

Hyōshigi [拍子木]: wooden clappers

Ichiban daiko [一番太鼓]: literally 'first drum'; a rhythm played thirty minutes prior to a rakugo performance in front of the yose theatre to indicate the imminence of a performance

Ichimon [一聞]: artistic family (for example, Hayashiya ichimon, Beichō ichimon)

Jiuta [地唄]: songs of the country

Jōruri [浄瑠璃]: recitation

Kabuki geza ongaku [歌舞伎下座音楽]: Kabuki offstage music

Kaidan banashi [怪談話]: ghost stories

Kamigata [上方]: the Kansai region of Japan

Kikkakechō [きつかけ帳]: cue book

Kimono [着物]: traditional Japanese garment

Kobanashi [小噺]: short rakugo stories

Kōdan [講談]: a professional narrative art form, often discussed alongside rakugo (also kōshaku)

Kōka ongaku [効果音楽]: music and musical sound effects incorporated into Kamigata rakugo perfomances (also hamemono)

Kōshaku [講釈]: a professional narrative art form, often discussed alongside rakugo (also kōdan)

Koten rakugo [古典落語]: classical rakugo; stories composed prior to the Meiji era (1868-1912)

Kōtō denshō [口頭伝承]: passing down a tradition orally

Kotsuzumi [小鼓]: hourglass-shaped drum

Kouta [小唄]: short song

Kuromisu [黒御策]: literally ‘black curtain'; offstage musicians' room in Kabuki theatre

Makura [枕]: a prologue to the rakugo story proper

Manzai [漫才]: two-person stand-up comedy

Misemono [見世物]: variety act(s) such as tricks, acrobatics, mimicry, dance

Nagabachi [長バチ]: long [drum] sticks

Nagauta [長唄]: literally 'long song'; vocal shamisen genre 
New Voices Volume 6

Nakairi [中入り]: intermission

Nakairi shagiri [中入りしやぎり]: a rhythm played by the narimono instruments to indicate the commencement of intermission.

Narimono [鳴り物]: refers to percussion and flutes of the yose-bayashi ensemble, and also to the repertoire of music played solely by the aforementioned instruments.

Niagari [二上がり]: literally 'raise the second'; a tuning of the shamisen

Niban daiko [二番太鼓]: literally 'second drum'; a rhythm played by the narimono instruments five minutes prior to a rakugo performance inside the yose theatre to indicate the imminence of a performance

Ninjō banashi [人情話]: stories of human compassion

Nōkan [能管]: Noh flute

Ochi [落ち]: ending punch line

Ōdaiko [大太鼓]: large barrel drum

Ohayashi [お囃子]: music played during performances at the yose theatre (also geza-san)

Ohayashi-san [お囃子さん]: specifically refers to the women (shamisen players) of the yose-bayashi ensemble (also geza-san)

Oidashi [追出し]: a rhythm played at the conclusion of a rakugo performance (also hane daiko, bare daiko)

Ōkawa [大鼓]: small drum

Okedō [桶胴]: folk drum with two heads lashed together

Ongyoku banashi [音曲話]: stories with shamisen accompaniment

Otoshi banashi [落とし話]: stories ending with a joke or pun

Rakugo [落語]: traditional Japanese comic storytelling

Rakugoka [落語家]: rakugo storyteller, synonymous with hanashika (hanashika is preferred in Kamigata rakugo)

Sagebayashi [下囃子]: withdrawal song (also ukebayashi)

Sansagari [三下がり]: literally 'lower the third'; a tuning of the shamisen

Seiza [正座]: sitting with ones legs folded under oneself

Sensu [扇子]: folding paper fan

Sha-mēru [写メール]: a photograph or image sent by mobile phone

Shamisen [三味線]: three-stringed plucked lute

Shibai banashi [芝居話]: 'theatre' stories; a genre of rakugo stories heavily influenced by Kabuki theatre

Shimedaiko [締め太鼓]: small barrel drum 
Shinobue [篠笛]: transverse bamboo flute (also takebue)

Shinsaku rakugo [新作落語]: literally 'new rakugo'; refers to rakugo stories composed during or after the Meiji era (1868-1912)

Shishō [師匠]: a master of a traditional art such as tea ceremony, flower arranging, Kabuki or rakugo.

Shümei [襲名]: receiving another professional performer's name

Sōban [双盤]: gong

Takebue [竹笛]: transverse bamboo flute (also shinobue)

Tèma songu [テーマソング]: theme song

Tenugui [手拭い]: handkerchief / small cotton hand towel

Tsuke [ツケ]: striking wooden clappers on a wooden board

Uke [受け]: withdrawal song (also ukebayashi)

Ukebayashi [受け囃子]: withdrawal song

Yose [寄席]: vaudeville-type variety theatre

Yose-bayashi [寄席囃子]: ohayashi music; ensemble of the yose theatre

Zabuton [座布団]: a square cushion used for sitting

Zenza [前座]: literally 'first seat'; first stage of the training involved in becoming a professional storyteller

Zokkyoku [俗曲]: popular song 
New Voices Volume 6

\section{Kamigata Rakugo Ichimon (Artistic Families)}

In the Kamigata region, there are 216 storytellers affiliated with the Kamigata Rakugo Kyōkai (Kansai Rakugo Association) ${ }^{83}$ Every storyteller is affiliated with an ichimon (artistic family). A list of the Kamigata rakugo artistic families is provided below. ${ }^{84}$ Due to the complexity of the artistic families and the number of current storytellers, only the storytellers mentioned in this paper are listed under their respective artistic families and in order of rank.

Katsura Beichō ichimon [桂米朝一門]

Katsura Jakujaku [桂雀々] (b.1960)

Katsura Yoneza [桂米左] (b. 1965)

Tsukitei ichimon [月亭一門]

Katsura Bunshi ichimon [桂文枝一門]

Katsura Bunshi V [桂文枝 V] (1930-2005)

Katsura Bunshi VI [桂文枝VI] (b. 1943), formerly Katsura Sanshi [桂三枝]

Katsura Bunbuku [桂文福] (b. 1953)

Katsura Bunza V [桂文三] (b. 1967)

Katsura Sanjaku [桂三若] (b. 1970)

Katsura Sankin [桂三金] (b. 1971)

Katsura Harudanji ichimon [桂春団治一門]

Katsura Fukuraku [桂福楽] (b. 1959)

Katsura Harusame [桂春雨] (b. 1964)

Katsura Fukusha [桂福車] (b. 1961)

Shōfukutei ichimon [笑福亭一門]

Shōfukutei Jinchi [笑福亭仁智] (b. 1952)

Shōfukutei Gakkō [笑福亭学光] (b. 1954)

Shōfukutei Kakushō [笑福亭鶴笑] (b. 1960)

83 Yamada, op. cit., p. 23.

84 For further information on Kamigata rakugo storytellers and the artistic families see ibid. 
Mori no ichimon [森乃一門]

Tsuyu no ichimon [露の一門]

Hayashiya ichimon [林家一門]

Hayashiya Somemaru III [林家染丸 II] (1867-1952)

Hayashiya Somemaru IV [林家染丸 IV] (b. 1949), formerly Hayashiya Someji II [林家染二 II]

Hayashiya Someji [林家染二] (b. 1961)

Hayashiya Kosome V [林家小染 V] (b. 1963) 


\section{New Voices Volume 6}

\section{Reference List}

Aiba, A., Gendai kamigata rakugo benri jiten [上方落語便利事典] (Tokyo: Shōnensha, 1987).

Brau, L., Rakugo: Performing Comedy and Cultural Heritage in Contemporary Tokyo (Lanham, Maryland: Lexington Books, 2008).

Hayashiya, K., Kikkakechō [きつかけ帳] (unpublished, 2011).

Hayashiya, S., Geza-bayashi kenkyū dai isshū [下座囃子研究第一集] (unpublished, 1984).

Hayashiya, S., Geza-bayashi kenkyū dai nishū [下座囃子研究第二集] (unpublished, 1984).

Hayashiya, S., Kamigata rakugo yose-bayashi no sekai kaisetsuhen [上方落語寄席囃子の世界解説編] (Osaka: Sōgensha, 2011).

Imada, K., 'Lupin III and the Gekiban Approach: Western- Styled Music in a Japanese Format', in Coyle, R. (ed.), Drawn to Sound-Animation Film Music and Sonicity (London: Equinox Publishing, 2010), pp. 174-190.

Katsura, B., Kamigata yose-bayashi daizenshū kaisetsu [上方寄席囃子大全集解説] (Osaka: Nenshōsha, 2004).

Kikkawa, E., Hōgaku hyakka jiten: Gagaku kara min’yō made [邦楽百科辞典:雅楽から民謡まで] (Tokyo: Ongaku no Tomosha, 1984).

Kodera, G., Misemono zasshi [見世物雑志] (Tokyo: San’ichi Shobō, 1991).

Koten Geino Kenkyūkai (ed.), Nihon no koten geinō: Yose [日本の古典芸能:寄席] (Tokyo: Heibonsha, 1971).

Maeda, I., Kamigata engei jiten [上方演芸辞典] (Tokyo: Shuppan, 1966).

Malm, W., Traditional Japanese Music and Musical Instruments (Tokyo; New York: Kodansha International, 2000).

Mita, J., Yose-bayashi gaisetsu [寄席囃子概説] (Tokyo: Kokuritsu Geijō, 1979).

Morioka, H. and Sasaki, M., Rakugo: The Popular Narrative Art of Japan (Cambridge, MA, and London: Council on East Asian Studies, Harvard University, 1990).

Nagata, Y., Koten rakugo kanshō jiten [古典落語鑑賞事典] (Tokyo: Kin’ensha, 1969).

Nobuhiro, S., 'Yose, Misemono' [寄席見世物] in Geinōshi Kenkyūkai (ed.), Nihon Shomin Bunka Shiryō Shusei 8 [日本 庶民文化資料集成8] (Tokyo: San’ichi Shobo, 1976).

Osada, S., 'Kamigata rakugo hamemono kikkakechō 1’ [上方落語ハメモノきつかけ帳1], Geinō Konwa [芸能懇話], vol. 2 (1990), pp. 17-25.

Osada, S., 'Kamigata rakugo hamemono kikkakechō 3’ [上方落語ハメモノきつかけ帳3], Geinō Konwa [[芸能懇話]], vol. 4 (1991), pp. 16-25.

Osada, S., 'Kamigata rakugo hamemono kikkakechō 8’ [上方落語ハメモノきつかけ帳8], Geinō Konwa [芸能懇話], vol. 9 (1995), pp. 47-56.

Osaka Shiritsu Engei Shiryōkan (ed.), Kamigata engei taizen [上方演芸大全] (Osaka: Sôgensha, 2008).

Ōshima, K., 'Rakugo and Humor in Japanese Interpersonal Communication', in Davis, J. (ed.), Understanding Humor in Japan (Detroit: Wayne State University Press, 2006), pp. 99-109. 
Sekiyama, K., Yose misemono zasshi: Nagoya yose kōgyōshi [寄席見世物雑志:名古屋寄席興行史] (Nagoya: Taibundō, 1968).

Sekiyama, K., Yose misemono [寄席見世物] (Tokyo: San’ichi Shobō, 1976).

Shōfukutei, S., 'Kamigata hanashika debayashi’ [上方噺家出囃子], in Katsura, B. (ed.), Nna Aho Na [んなあほな] (Osaka: Kamigata Rakugo Kyōkai, 2006), pp. 8-10.

Shores, M., 'Travel and Tabibanashi in the Early Modern Period: Forming Japanese Geographic Identity', Asian Theatre Journal, vol. 25, no. 1 (2008), pp. 101-21.

Tōdai Rakugokai (ed.), Rakugo jiten [落語事典] (Tokyo: Seiabō, 2010).

Tokita, A. and Hughes, D., 'Context and Change in Japanese Music', in Tokita, A. and Hughes, D. (eds.), The Ashgate Companion to Japanese Music (Aldershot: Ashgate, 2008), pp. 1-33.

Ui, M., Kamigata hanashi kō [上方落語考] (Tokyo: Seiabō, 1965).

Ui, M., Rakugo no keifu [落語の系譜] (Tokyo: Kadokawa Shoten, 1975).

Yamada, R., Kamigata rakugoka meikan [上方落語家名鑑] (Osaka: Shuppan Bunkasha, 2006).

Yamamoto, S., Rakugo handobukku [落語ハンドブック] (Tokyo: Sanseidô, 2001). 